\title{
Profiles in Intelligence: An Interview with Professor Christopher Andrew
}

\author{
Mark Phythian
}

\section{School of History, Politics \& International Relations, University of Leicester, UK}

\section{Introduction}

Christopher Andrew has been at the forefront of the study of intelligence over the last five decades. During this time he has produced a series of landmark works that have transformed our knowledge and understanding of the role of intelligence in the United Kingdom, the Soviet Union, the United States, and beyond. Indeed, through his published work and wider activities he has made one of the most significant contributions to the development of Intelligence Studies as a discrete area of academic inquiry, alerting historians to the extent to which intelligence constituted a 'missing dimension' of international history that needed to be addressed. Beyond his own published work, his commitment to mentoring subsequent generations of academics who have themselves gone on to become leading figures in the study of intelligence has helped ensure that this 'missing dimension' has been progressively revealed and incorporated into historical writing. Without his pioneering work, the study of intelligence would almost certainly have progressed differently, more slowly and without the sense of identity that the establishment of this journal and linked initiatives, such as the Studies in Intelligence book series, have helped to create.

Christopher Andrew has spent his academic career at Corpus Christi College, Cambridge, where he is currently Emeritus Professor of Modern and Contemporary History. That there must be a 'missing dimension’ first struck him while conducting archival research for his $\mathrm{PhD}$ on the Entente Cordiale. He retained an interest in researching the role of intelligence thereafter, although the obstacles to doing this were even greater in the 1970s and 1980s than they are today. In this context, in 1985 he produced a pioneering study of the making of the British intelligence community, Secret Service, in the Preface to which he reflected on the challenges facing the historian of intelligence at the time. A number of significant journal articles followed before he began his collaboration with Oleg Gordievsky after the latter's escape from the Soviet Union. This resulted in the publication of three volumes on the KGB, including the 700-page history, KGB: The Inside Story. By this time he had also co-founded, 
in collaboration with US academic and expert on strategic surprise Michael Handel and publisher Frank Cass, this journal, Intelligence and National Security, which was first published in 1986. He would serve as founding co-editor with Michael Handel over its first decade, overseeing its development as the leading academic journal in what was coming to be recognised as a discrete subject area, Intelligence Studies.

A detailed history of US Presidents and secret intelligence, For the President's Eyes Only, was published in 1995. This was followed by a lengthy collaboration with another KGB defector, Vasili Mitrokhin, which resulted in the pathbreaking two-volume The Mitrokhin Archive, the first volume appearing 1999 and the second in 2005. The publication of the second volume, dealing with KGB operations in Africa, Asia, Latin America and the Middle East, was extensively delayed as the geographical sweep of the book created more complex problems in securing official clearance of the text and by the time it came out Mitrokhin had died. Also by this time, the British Security Service, MI5, had advertised for an official historian to produce its Centenary History. Christopher Andrew was appointed to this role and in 2003 began work on what became The Defence of the Realm: The Authorized History of MI5, the indispensable 1,000-page account of MI5's development, published in 2009.

Beyond his publications, Christopher Andrew has done much to popularise the study of intelligence, with contributions ranging from regular talks to a wide range of audiences, to radio programmes and television documentaries, and regular podcasts introducing and reviewing the annual releases of Security Service files at the National Archives (see, http://media.nationalarchives.gov.uk/index.php/author/professor-christopher-andrew/). He is currently completing his latest project, a history of intelligence from the earliest times to the present - Secret World: The Making of Modern Intelligence from Moses to the Twenty-First Century - which will be published by Penguin in 2018.

What follows is the edited transcript of an interview conducted with Christopher Andrew at Corpus Christi College, Cambridge, on $13^{\text {th }}$ July 2016.

\section{Interview}




\section{MP: Could I begin by asking you to say a little about how you became a historian of intelligence? Initially, your research focus was late $19^{\text {th }} /$ early $20^{\text {th }}$ century French foreign and imperial policy?}

CA: When I was an undergraduate even though I didn’t find examinations too frightening, and sometimes actually even quite liked them, the idea that I might become an academic did not occur to me until my last year. Then, having decided to do historical research I had two ideas in my head. The first one was that it shouldn't be Britain. I think there is an awful lot to all historical platitudes - if they weren't true they wouldn't become platitudes - so the great line 'What does he know of England who only England knows?'. One of the reasons, without any offence to non-travelling English historians, why Bob Tombs' history of England ${ }^{1}$ is in a class of its own is that he knows continental history, in particular French history. This makes it possible to distinguish what is run-of-the-mill in English history from what is distinctively English. So that thought was in my head. And then, as people occasionally did in those days, but don't do nearly so frequently now, we got married soon after my graduation, so Jenny and I discussed together whether we would sooner spend a year in Paris, a year in Rome, or a year in Madrid. And this was a tough one! And in the end we decided that we would prefer to spend the middle of the three years of research in Paris.

Now what was I going to work on? I did start from first principles, and the first principle was that it should be something just beyond the 50 -year rule (there was a 50 -year rule in those days) and, secondly, that it should be sufficiently important to appear in the index of the Penguin History of France. Little did I know, because my supervisor - a fine man, Patrick Bury ${ }^{2}$ - didn’t know, they didn't have a 50-year rule in France! And indeed the papers that I wanted to see, even though they were over 50 years old, nobody had ever seen before. That was how I came to work on the Entente Cordiale and I chose as the focus the only man in the entire history of the Third Republic, where governments changed on average every eight months, to last seven years as Foreign Minister, Théophile Delcassé.

Then I began trying to look at his papers and I discovered that the way to do it was finding somebody who knows somebody. There were two, one became a dear friend, Jacques Millerand, who was the son of Alexandre Millerand who had been successively Prime Minister

\footnotetext{
${ }^{1}$ Robert Tombs, The English and Their History (London: Allen Lane, 2014).

2 J. P. T. Bury (1908-87), historian of France best known for his classic history of modern France, France, 1814-1940 (London: Methuen, 1949) and three-volume biography of Léon Gambetta.
} 
and President of France. Then I got to know also the best-known, very senior as she was by that time, French foreign correspondent Geneviève Tabouis, and both of these people put in a good word for me. The head of the archives was furious, but having been given instructions to let me see the papers of Delcassé he had no alternative. I went into his room and I made my first mistake. I extended my hand, which was refused. He sat me down. He read out the instructions from the Foreign Minister, Maurice Couve de Murville, who interestingly lasted longer as French Foreign Minister than any other Foreign Minister since Delcassé. He said that the instructions of the Minister would be complied with, and that I would be under constant surveillance to guard against the risk of theft. With that warm greeting I concluded that my time in his office was over.

So how did I get from that into intelligence? Well I had no specific interest in intelligence. Why? Because like most people I regarded it as cloaks and daggers. What has that got to do with serious history? We don't need to ask that question now, but I am sure that one of the reasons for the slow development of intelligence history has been the fact that intelligence is the only profession in which fictional characters have for the last century and more been far better known than real individuals - and that is still true of James Bond, and not simply Bond. So taking it seriously was quite difficult.

However, in the course of my research I began to realise that the French must have had access to some German diplomatic telegrams. I remember being in the University Library here and having open on my library desk Die Grosse Politik, the German diplomatic documents, and the Documents Diplomatiques Français and concluding that one could understand Delcassé's policy if he had read some of the documents in Die Grosse Politik - but he couldn't have read them, could he? Oh, perhaps he could! When I got to see his papers I realised that he did, and this is still a period when in the published diplomatic documents all SIGINT was edited out. What would happen is that if there was an intercept it wouldn't be quoted in the published document, there would be some dot dots and there would be a little note at the bottom paraphrasing some of what had been omitted but concealing the secret source. So I found this extremely interesting.

I think the book of my PhD, Théophile Delcassé and the Making of the Entente Cordiale, ${ }^{3}$ was probably the first to mention French code-breaking in that period (though this wasn't the main

\footnotetext{
${ }^{3}$ Christopher Andrew, Théophile Delcassé and the Making of the Entente Cordiale: A Reappraisal of French Foreign Policy 1898-1905 (London: Macmillan, 1968).
} 
theme of the book), but I just assumed that this area was generally unresearchable. Certainly, in terms of historical research, getting hold of SIGINT in Britain was next to impossible. And even the words were unknown to the best French historians. The first article that I wrote about French SIGINT over a significant period, which was in the early 1970s, I called Déchiffrement et diplomatie: Le cabinet noir du Quai d'Orsay sous la Troisième République. ${ }^{4}$ But déchiffrement is the wrong word; decipherment is not code-breaking - if you don't know the code you decrypt, not decipher. And the French is the same - décryptage. Anyway, I began by calling it Décryptage... and showed it to a dear French friend, the holder of a major chair in a major French university, and he said 'the word doesn’t exist'. So I took it out.

Now that intelligence is part of mainstream history it is difficult for people working on the subject today to realise that quite a lot of its basic vocabulary was either unknown or forbidden, or both. So when in the early 1970s I gave my first talk on the subject to Harry Hinsley's ${ }^{5}$ seminar on international relations I called it 'SIGINT and French Foreign Policy in the Third Republic'. Now Harry when commenting on my paper had to say 'what Dr Andrew has referred to as SIGINT...' because even the word was classified. So there we are. I got really interested in an activity which amongst some brilliant French historians was an unknown word and one that Harry Hinsley had been working on in his twenties at Bletchley Park and didn’t feel able to mention a quarter of a century later.

\section{MP: I would imagine that studying under Harry Hinsley played a part in your developing} interest in this area?

CA: When I came back from Paris, Patrick Bury, who was a French historian, was on leave so as a substitute for my final year I had Harry Hinsley as my supervisor. Everyone who had Harry Hinsley as a supervisor for anything, including Charlemagne, was extremely glad that they had. I could see that he was extremely interested when I said 'people haven't realised how important

\footnotetext{
${ }^{4}$ Christopher Andrew, 'Déchiffrement et diplomatie: Le cabinet noir du Quai d'Orsay sous la Troisième République', [Decipherment and Diplomacy: The Black Chamber in the Third Republic] Relations Internationales No.5, 1976, pp.37-64.

${ }^{5}$ Sir Harry Hinsley joined Bletchley Park from Cambridge in October 1939 aged just 20 and went on to play a key role in decrypting and analysing German codes during the Second World War. See, Richard Langhorne, 'Hinsley, Sir (Francis) Harry (1918-1998)', Oxford Dictionary of National Biography, Oxford University Press, 2004; online edn, Jan 2010 [http://www.oxforddnb.com/view/article/69418, accessed 6 Feb 2017], and F. F. Hinsley and Alan Stripp (eds.), Codebreakers: The Inside Story of Bletchley Park (Oxford: Oxford University Press, 1993).
} 
it was breaking German codes', in reference to the period before the First World War. He did drop in something about having had an interest in such fields himself during the Second World War, but it was only some years later - this was 1964-65 when he was my supervisor (I graduated in 1962, took my PhD in 1965) - that the irony of what I was telling him became apparent. It was wonderfully ironic.

For some years after publishing an expanded version of my $\mathrm{PhD}$, I worked on French imperial expansion in collaboration with a Canadian friend and colleague in Cambridge, Sydney KanyaForstner, before he returned to Canada, ${ }^{6}$ but I remained interested in looking at the intelligence angle when the intelligence angle was researchable.

One summer vacation, I went over to stay at a friend's house in Paris and I spent some time in the Archives Nationales. I noticed just looking down the list of recent papers opened that they had papers from the service photographique. I knew what service photographique was; it was the cabinet noir, the code-breaking unit. So I copied as much of it as I could that day, in fear that it would be withdrawn the following day. That did once happen to me in Australia, so even though somewhat paranoid I wasn’t one hundred percent paranoid.

That led me on to other things. In Britain the opportunity came with the controversy over the Zinoviev Letter in the late 1960s. I was quite inclined to believe it was genuine because there were documents like that that were genuine - you could only tell if a specific document was genuine if you had access to the original files. The main point I wanted to make was that what many historians, as it seemed to me, had got wrong was that this is not an isolated example, it's just an example of a routine activity which for particular reasons becomes publicly known and produces a public scandal. So that got me into the British side. Now I still didn't think that the subject of intelligence was wholly researchable, but there were obviously some areas that were researchable. In those days (the 1960s, 1970s), there were still really quite a lot of people in Cambridge - not simply in Cambridge, but there were a higher percentage in Cambridge than elsewhere - who had worked in Bletchley Park, including three couples who had met and married while they were at Bletchley Park - the Hinsleys being one example. I started doing initially radio programmes with these people and it gave me a real insight. This was the first time probably in the history of any British university in which some of the best students had

\footnotetext{
${ }^{6}$ Producing, for example, France Overseas: The Great War and the Climax of French Imperial Expansion, with A.S. Kanya-Forstner (London: Thames and Hudson, 1981).
} 
been given the opportunity to show that they were better than the lecturers. And the classic example of that, but not the only one, is Harry Hinsley who was recruited at the end of his second year at Cambridge and outclassed a number of more senior colleagues at Bletchley Park, one of whom, Jack Plumb, ${ }^{7}$ probably never fully forgave him.

So then it occurred to me that it would be possible to do a radio series on the history of British intelligence since late Victorian times, 'The Profession of Intelligence' ${ }^{8}$ Having put it all together for a radio series I began to realise that it would be possible to write a book on it. That was the genesis of the first book that I wrote on British intelligence. ${ }^{9}$

\section{MP: Do you think being at Cambridge yourself helped fire your interest in this area, given the history?}

CA: I think the answer would be not originally. But later on, in the course of research, it made it a.) easier and b.) more interesting, because there were plenty of connections I could make and I had some understanding of the culture. The first thing that struck me was that many other universities, Leicester included, send some of their finest into the intelligence services, but in the case of Leicester I am sure that it is into our own side. Cambridge has had a more cosmopolitan tradition than so many other universities. Trinity College used to be fond of mentioning that it had produced more Nobel Prize winners than the whole of France - perfectly true - it was less fond of mentioning that it produced more world-class traitors than the whole of Oxford, but that is also true. And, of course, there were still people around who actually knew some of these people, so it gave me a better feel for it.

MP: In the late 1980s-early 1990s, your research focus shifted to Soviet intelligence and the activities of the KGB, and you published three volumes in collaboration with Oleg Gordievsky. How did that collaboration come about?

\footnotetext{
$7 \mathrm{~J}$. H. Plumb was a renowned historian of the eighteenth century, best known for England in the Eighteenth Century (London: Pelican, 1950) and The Growth of Political Stability in England 16751725 (London: Macmillan 1967). During the Second World War he worked at Bletchley Park on German naval signals.

${ }^{8}$ A five-part series for BBC Radio 4 broadcast in 1981.

${ }^{9}$ Christopher Andrew, Secret Service: The Making of the British Intelligence Community (London: William Heinemann, 1985).
} 
CA: There were a number of things going on at the same time and you get a series of unexpected opportunities for a number of reasons. One is because the more research you do in a particular area, the more dots you know and therefore the more dots you can turn up and sometimes connect. Secondly, people know you have been doing work in this area. It wasn't the only reason, but here's the immediate reason that I got to know Oleg Gordievsky. ${ }^{10}$ In Secret Service it was really the lack of perspective which struck me on a lot of books on international relations and British history, one that is summed up in the title of the book I edited with David Dilks, The Missing Dimension. Nowadays nobody would write a book on international relations over the last half century and more without mentioning the intelligence dimension. In those days it was common practice. So one of the things that I put in Secret Service was that it is naïve to suppose that there have been no major British Soviet agents since Oleg Penkovsky around the time of the Cuban Missile Crisis simply because their names have yet to appear in the newspapers. The next day, Oleg Gordievsky's name appeared in the newspapers. Everybody is entitled to one undeserved act of serendipity like that. That was one of the things that interested him about me. Of course, if the authorities had said that you don't want to touch that man Andrew, no doubt he wouldn’t have done so.

We first met in London in 1986 and then he came down to Cambridge and we agreed to write a book and he said 'Is there anything you would particularly like to know?' I said, 'Yes; as we are in Cambridge, who was the Fifth Man?' To which he immediately replied 'John Cairncross'. So I asked him who the recruiter was and he said Dr Arnold Deutsch. The name, for those who are interested in the area, is moderately well-known and perhaps very wellknown to specialists, but was not known at that point. ${ }^{11}$ Now here's how serendipity goes. What was known about him? Well, that he came from Vienna. So the odds are he went to Vienna University. So I wrote off to Vienna University and got his transcript, and to my amazement it even included a little CV in his own hand. Now I could immediately see from the $\mathrm{CV}$ one of the reasons he was chosen. He had an academic record that was even brighter than those of his star pupils, the Cambridge Five. He went from admission as an undergraduate

\footnotetext{
${ }^{10}$ The fullest account of Gordievsky's background, career, work for SIS, and defection from the Soviet Union is to be found in Oleg Gordievsky, Next Stop Execution: The Autobiography of Oleg Gordievsky (London: Macmillan, 1995). See also the Introduction in Christopher Andrew and Oleg Gordievsky, KGB: The Inside Story (London: Hodder \& Stoughton, 1990), pp. xix-xxxii.

${ }^{11} \mathrm{See}$, for example, the gap this creates in Phillip Knightley's biography of Kim Philby, first published around this time; Philby: KGB Masterspy (London: Andre Deutsch, 1988).
} 
to $\mathrm{PhD}$ with distinction in five years. His $\mathrm{PhD}$ was in Chemistry but he was taking Psychology classes.

So what did I do? Well, I happened to have a friend who was teaching at the time in the Theresianum, which is the Eton of Vienna, and I gave him Deutsch's address and asked would you kindly take photos sometime when you are passing. He did and sent them to me, and what amazed me is that there was a monument to him outside his apartment, and this wasn't because he was the best agent recruiter the KGB ever had, which he probably was, but because he had also been a member, not I think for very long, of the Austrian Resistance. This meant that there was going to be a file in the Widerstand Archive, and so there was - a pretty thin file, but extremely interesting. It reported that he had gone missing in April 1934. Well, that fits because he had gone over to London because he had an appointment to recruit Kim Philby in Regent's Park that very month. So this was getting better and better. But the thing that if I had been given a hundred guesses I wouldn't have come close to is which branch of the Viennese police was after him; it was the "anti-pornography" section. Why? Well, not because he was in any sense a pornographer, but that he was the assistant and publisher of the great sexologist of the period, Wilhelm Reich, who was also a communist. ${ }^{12}$ Even in the university library I was able to look at some of Reich's books and, where the publisher's name ought to be it says, 'MünsterVerlag (Dr Arnold Deutsch)'. So there was no better person for Moscow to send to Trinity College and sort out this group of five very sexually active individuals (two heterosexual, two gay, one bisexual).

One of the things that Gordievsky knew was that Arnold Deutsch had had a daughter while in London. So Jenny went off to what was the Births and Deaths Registry then in Somerset House and got the birth certificate of Nina Deutsch, who I subsequently interviewed for a Granada television programme. What the birth certificate gives you is the name and profession of the father, if the father is mentioned, and it also gives you the address. Having discovered that this is where Arnold Deutsch lived with his wife and his baby daughter, I went along with the television film crew to Lawn Road Flats, Hampstead, in the epicentre of Britain's chattering classes in London. ${ }^{13}$ It was a deck access block of flats which at the time was tremendously fashionable, the first one in Britain. Now you only see them in old episodes of The Bill or

\footnotetext{
${ }^{12}$ See, Christopher Andrew and Vasili Mitrokhin, The Mitrokhin Archive: The KGB in Europe and the West (London: Allen Lane, 1999), pp.73-83.

${ }^{13}$ See, David Burke, The Lawn Road Flats: Spies, Writers and Artists (Woodbridge: The Boydell Press, 2014).
} 
something like that as a sink estate. So there I was, standing almost outside Arnold Deutsch's flat. His was one of the few that was in a stairwell; all the others you could see from the street. So, holding up his birth certificate, I said, 'For it was here...' and no sooner had I got that part of the sentence out of my mouth than a woman came out of the next door flat and said 'Oh no, not another film about her'. I asked who she had in mind and she said 'Agatha Christie, of course' - she had the next door flat. I immediately thought, but without any justification, of them coming out onto the balcony and him saying to her, 'What's going on on the Orient Express then?' while she would wittily say, 'Who else have you recruited from Trinity?' Alas, their time in Lawn Road Flats didn’t quite overlap.

So I had the opportunity to branch out into the history of Russian intelligence, which was a gamble and a leap. But a simple rule of life is that when you are offered a wonderful opportunity you shouldn't turn it down, even if it's not the opportunity you were expecting. So the four year period from 1986 to 1990 was absolutely wonderful because not merely was I writing a book with Gordievsky, but he was also giving me a running commentary on the end of the Cold War.

While I was doing all that, I had planned shortly before I met Gordievsky to go and do some research in Australia, because what I was going to do was imperial intelligence. I had a really good time at the Australian National University in Canberra and I interviewed (with the exception of one former diplomat who had become head of ASIS and didn't want to be interviewed) all the surviving heads of ASIS and ASIO and I wrote that up, mainly in Australia. So the work with Oleg overlapped with other things, and then I spent some time also at the Wilson Center in Washington, DC. Then fast-forwarding to 1988-89, Oleg came to stay with us for a couple of Christmases and happened to be there just as the Soviet bloc was finally falling apart on Christmas Day 1989. Sitting on the sofa with Oleg, watching these terrible pictures of the Ceausescus being arrested and taken off for the kind of end which they had subjected other people to, was really a pretty extraordinary way for our whole family to witness the end of the Cold War.

What did that lead on to? I published KGB: The Inside Story with him. I think that of most enduring value are the couple of volumes of KGB documents we published, and we had to be 
careful about that. ${ }^{14}$ There was no problem from HMG. However, his wife Leila and his small daughters in Russia still weren't allowed out and my original suggestion for the title, Comrade Kryuchkov's Instructions - Kryuchkov being at that point the last head of the KGB - was thought to be too provocative. So it was turned into Instructions from the Centre and even then it wasn’t published until 1991.

In December 1990 I was able to deliver to Leila Gordievsky in Moscow a few hundred dollars, a lot of money in those days - Oleg's money, not mine. My thinking was that because I was filming a documentary for the BBC I wasn't going to get hassled. It's difficult now to remember, but Gorbachev had given effectively strict instructions 'don't mess with the BBC'. The openness really did mean that the BBC and a few other foreign broadcasting companies were not aggravated. Anyway, I could have stayed with the producer and the rest of the BBC team in a modernised hotel in the centre of Moscow, but I chose instead to stay in one of the traditional ones, the Ukraina, one of the Stalinist wedding cakes and at that point alleged to be the biggest hotel in Europe. I was flattered by the attention I received from the KGB. They made no attempt to intimidate me. At breakfast time there was somebody standing by both restaurant doors but they didn't interfere, not even when a waiter sold me some caviar under the table for five dollars. I first met Leila in my (doubtless bugged) hotel room and gave her the money and a roll-bag of warm clothes which Oleg had sent over for the children, not making them too attractive so they didn't attract envy from their class mates. So I have actually been able to engage in mildly secret operations in Moscow without aggravation. I wouldn't dare do so now.

In those days it was a good idea, even if, like me, you were a non-smoker, to buy packets of Marlboro cigarettes from the duty-free trolley on the flight to Moscow. Russian taxi-drivers liked others, but for some reason Marlboro were the most popular ones. So I got two packs of 200 and then I went with Leila and we stood by the roadside waiting for a few taxis to go past, held up twenty Marlboro, the next taxi halted, we got in and were able to talk, away from the bugged hotel room, about Oleg and various other things. I began by looking out of the rear window and said to Leila, 'What's it like being followed by three KGB cars everywhere you

\footnotetext{
${ }^{14}$ Christopher Andrew and Oleg Gordievsky, Instructions from The Centre: Top Secret Files on KGB Foreign Operations 1975-1985 (London: Hodder \& Stoughton, 1991); More Instructions from The Centre: Top Secret Files on KGB Global Operations 1975-1985 (London: Frank Cass, 1992).
} 
go?' She replied, 'No, two', and I said, 'No, one, two...', and was about to say 'three' when I had this overwhelming sense of self-importance; one of them was for me! When you take into account the shift system, and calculate the resources that were put on following me - if it was MI5 it would need to be a really major target. Anyway, the BBC crew was very good company and I enjoyed filming in the white and gold room in the British embassy and so on. That evening we went to have a nice dinner with Leila Gordievsky at a new private restaurant near Gorky Park. I would like to be able to tell you that it was minus twenty outside. It wasn't, but nonetheless it was well below zero and the three cars full of goons had to keep their engines running so as not to freeze. So we could have been regarded as provocative when we took our champagne to the windows. This was December 1990, and then in August 1991, after the failed coup there, John and Norma Major had a pre-arranged visit to Moscow and Leila and the children were allowed out. Alas, the marriage, perhaps unsurprisingly given what both of them had had to endure, never really got back together again.

\section{MP: How did you actually collaborate with Oleg Gordievsky in writing the history of the KGB and the documents books?}

CA: The methodology was simply to pull together everything that was available from sources in the West, considerably less than would be available now, and then add on to it what Oleg knew from KGB files and his own experience. He knew quite a lot for two reasons. One is that before working for the British he wanted to be damn sure that there weren't Soviet agents in MI6 who might betray him. He was recruited in 1974 in Copenhagen, and from 1978 to 1982 he was back at the Centre (KGB HQ). He was in the third department of the First Chief Directorate, and the third department actually lumped together Britain, Scandinavia, for some reason Australasia and, less surprisingly, Ireland. So he was able during those years to shift over from being a Scandinavian specialist to being a British specialist. As for the documents, he was able to go through quite a number of British files. He has a clear memory, although he wouldn't swear to it, of going to collect the Anthony Blunt file and as the shutter went up the archivist who handed it over to him was Vasili Mitrokhin. It was at that point that he was able to establish who the Magnificent Five were. It is now difficult to remember that even though John Cairncross, the Fifth Man, had been identified as involved with Soviet intelligence, he had not been identified as the Fifth Man because the significance of the jobs he had had, which 
had included in particular being the only one to penetrate Bletchley Park, had not been adequately realised.

I think the operational decision taken by MI6 in 1978-82 that it was too dangerous to run Gordievsky in Moscow was absolutely correct. Oleg Penkovsky, after all, had been caught while working for MI6 in Moscow on the eve of the Cuban Missile Crisis. Sooner or later, the level of surveillance being what it was, Gordievsky would have been quite likely to be caught. Then, of course, that wonderful day in London in 1982 when the FCO get the list of the latest visa requests from Moscow and one is for a new political counsellor at the Russian Embassy, O. Gordievsky.

The second reason why he discovered quite a lot in KGB files was that he also had a strong historical and international relations perspective which extended well beyond operational intelligence detail. The files he was able to study and sometimes photograph while working for MI6 in Copenhagen from 1974 to 1978 were predominantly but not wholly Scandinavian. They include quite a lot on global operations against the United States ('the main adversary') such as attempts to discredit the American Bicentennial. There were also quite a number of general policy directives, and then the crucially important material when he was stationed in London from 1982 to 1985 was without doubt Operation RYAN and the secret Able Archer crisis. ${ }^{15}$ Oleg and I were agreed from the beginning of our collaboration that it had been too frequently assumed that the frequent, though by no means continuous success of Soviet intelligence collection had been reflected in KGB intelligence assessment. Not so, and there is now a large amount of material which demonstrates that assessment was clearly inferior to collection. Operation RYAN is a classic example. Telling the Soviet leadership what it wanted to hear, blaming the Americans, and falling back on conspiracy theory: these were staples of KGB intelligence assessment which were not sufficiently recognised at the time.

\section{MP: There is an interesting literature on the way ideology distorted intelligence.}

CA: That's right, but I think that the most important thing was actually the authoritarian element rather than the particular nature of the authoritarian ideology. In other words, through the ages one can see similar distortions in the information given to the ruler in quite different authoritarian regimes. It takes different forms in modern one-party states from, let's say, the

\footnotetext{
${ }^{15}$ See the KGB directives on Operation RYAN in Andrew and Gordievsky, Instructions from The Centre.
} 
Ming dynasty, but I think the key element is the authoritarianism of the regime rather than the particular nature of the ideology.

When writing KGB: The Inside Story, we had to limit ourselves in the number of actual quotations that we made from Gordievsky's documents because they would be regarded as very provocative at a time when his family were forbidden to leave the Soviet Union. Anyway, times changed with the disintegration of the Soviet Union, so we were able to publish a couple of volumes of documents, Instructions from the Centre (the title on this side of the Atlantic) and More Instructions from the Centre. Because the US edition came out later, after Kryuchkov had been imprisoned (although he got out after a few years), there we were able to call the first volume Comrade Kryuchkov’s Instructions.

MP: I would like to take you back to the early-mid-1980s, when you are at the centre of the development of the study of intelligence as an academic endeavour. In 1984, you edit The Missing Dimension with David Dilks, in 1985 your landmark study of the development of the British intelligence community, Secret Service, is published, and in 1986 you launch this journal, Intelligence and National Security, as co-editor with Michael Handel. How did that come about?

CA: Yes, there were a lot of things coming together at the same time. One other thing, and Michael Herman was involved in it very early, was the Study Group on Intelligence, which was simply an excuse for meeting together three times a year for a day conference, which still goes on (nowadays at RUSI). We were told by somebody who had access to JIC material that the foundation of this group was deplored but they felt that if it had to be founded, it might just as well be founded by us.

The great thing that I remember about the founding of Intelligence and National Security was how much fun it involved. Michael Handel and I came at the same subject from slightly different angles, which we both welcomed. We were also lucky to have Frank Cass as our publisher. There is a lot to be said if you are founding a new journal in a new area for having some really engaged entrepreneur rather than doing it through a university press. I have nothing against university presses which do much to preserve good scholarly standards, I spent ten years as editor of CUP's The Historical Journal and enjoyed that. But with Intelligence and National Security big decisions would be taken with Frank Cass coming down to Cambridge 
and taking me out to lunch. Michael Handel would come too if he was around, but Frank had his own ways of making contact with Michael. Frank fully shared our excitement.

The main credit does not belong to me. It was certainly Michael Handel who suggested that the three of us get together and then there was a founding lunch. I already had the ambition but I did not have a formula which would have produced the journal. I remember one of the first things I wanted to do was get SIGINT established as something that people would think about when writing history, and not just of the $20^{\text {th }}$ century. So the second issue of Intelligence and National Security was probably the first SIGINT special issue of any journal. I do remember at that time, even though nobody would say this now, that somebody from the US National Security Agency came up to me in a conference and said that one of the articles about the Second World War had done serious damage. One of the nice things was that there were still enough people who had been involved, particularly but not uniquely in the Second World War, to publish and put in an academic journal.

One of the things that Michael Handel was able to do while he was at Carlisle Barracks was get funds to put on a conference every year which served as a basis for special issues of the journal. There was one on Leaders and Intelligence ${ }^{16}$ and a number of others. I didn't organise any of those conferences in the early years but the archives at Carlisle Barracks were a revelation as far as I was concerned. Some material from the archives there did go into the book with Gordievsky, which was going on at the same time, because the Barracks held the records of one of the individuals who was involved in the discovery of Soviet electronic penetration of the US Embassy in Moscow. The US Embassy was conducting open diplomacy I would say until the early 1960s, but when they finally had an electronic sweep of the Embassy in 1944 over a hundred devices were discovered on day one. It was a little like me noticing service photographique. These particular documents were not from one of the commanding heights of American diplomacy, but they were by somebody who was seeing it from the ground.

I partly accepted and partly created opportunities as they came along, so the next one after Oleg Gordievsky was as Visiting Professor of National Security at Harvard University in 1992. I decided that I would do an article on how American presidents had used intelligence, and one article turned into three, and the three articles turned into a book, For the President's Eyes Only. So that was a predictable opportunity, except that I got more interested in it than I had thought. And I ran my first intelligence seminar there, because the great thing at Harvard is that

\footnotetext{
${ }^{16}$ Vol.3 No.3 1988, which included 'Churchill and Intelligence' by Christopher Andrew, pp.181-93.
} 
you can ask practically anyone in Washington to come along. And if it's the DCI they say, 'would next Wednesday be fine?' 'Yes, absolutely'. It's not quite like that, but it's not hugely different from that. And that's the first time I met Robert Gates.

\section{MP: You produced two major volumes on the KGB in association with Vasili Mitrokhin, based on the detailed notes that he took on KGB files over a 12-year period until his defection in 1992. How did this collaboration come about?}

CA: I was invited along to a briefing at SIS headquarters and told about the Mitrokhin material, which in the days before memory sticks was truly extraordinary. Then I met him; an entirely different personality from Gordievsky. Extremely estimable and-like Gordievsky-very brave, but Gordievsky had spent a considerable amount of time abroad. This man, Vasili Mitrokhin, after he had had a few foreign outings at the beginning of his career had spent all of his time in the archives, so he didn't have Oleg's broader view of the world in some ways. Some of the things that he wanted were entirely understandable but impracticable. He suggested a two million print run for the book. Well, of course, within the Soviet era if your Tales of Little Lenin is a book that is chosen, yes, two million is about it. I remember that at one point he rather hoped that The Sunday Times would serialise it every week for a year. But this is simply to illustrate the fact that even though his loathing of the Soviet system was entirely genuine, his understanding of day-to-day life in the West took a while to acquire. But Oleg and Vasili had one major thing in common. Like many other Soviet defectors, Western agents and dissidents, the 1968 Prague Spring was the turning point. Time after time if you ask them, that is what they pick out. They were all people who hoped that de-Stalinisation would continue (not a foolish idea at the time), who hoped for 'socialism with a human face'. They got it in the Spring of 1968 and in August the tanks came in. That's the point at which Sakharov, Solzhenitsyn, Gordievsky and Mitrokhin amongst others decide that the only thing to be done with the system is to bring it down. Now, if you are in the KGB you can either tell them 'you're all rotters and you deserve everything you get', which wouldn't achieve a lot apart from your incarceration, or you attempt to undermine it from within. And that's what they do, but in Mitrokhin's case he took notes, because he had this extraordinary responsibility for checking every file out at one end and checking it in at the other end during the move of the foreign intelligence archive to a new HQ. His normal method would be to transcribe the file summary on the outside and then anything that particularly interested him, depending on how much time 
he got, on the inside. The things he transcribed at greatest length had to do with the dissidents because those were the ones he had greatest fellow feeling with. My collaboration with him was an extraordinary privilege but not the close personal friendship that I had with Gordievsky. What he essentially wanted in addition to writing the books was for all the material to be available, and so did I, and that has come to pass more quickly than was reasonable to expect a decade ago. Since 2014 virtually all the Mitrokhin material is now available at Churchill College Archives. ${ }^{17}$ Despite the fact that it is, of course, in the Russian language and translation is not provided, it is one of the three archives that clearly attract more attention than any others: Churchill, Thatcher, and Mitrokhin. And people come from all around the world and in many cases those who come from smaller countries are likely to find more because we couldn't fit everything in the two books.

\section{MP: In methodological terms, this involved a very different approach to your earlier work with Oleg Gordievsky. What were the key differences?}

CA: Essentially what happened is that I had access to all the original material on a computerised database. The way that Mitrokhin presented it is given in the endnote and bibliography. All the references I give are the references which work in the Churchill College Archive as well. What Mitrokhin was very anxious for was that as much should be published as possible and instead of skimming off some of the highlights and putting them in one volume, there are two published volumes, one is about Europe and the West and the other is about the Third World. I would do chapters and get his comments. The most difficult chapter to write, not in the sense that there was any disagreement about it, was the chapter which described his career. He really wasn't interested in talking about that, but as he was a completely unknown character in Britain it seemed to me, and he did take the point that his personal story should precede the rest.

\section{MP: The project wasn't initially conceived as a two-volume work?}

CA: No, it was only when I really got into it that I realised that we wouldn't be able to do the material as much justice within a single volume. It would have been far easier to write if I had just picked the highlights. And the other problem, of course, I nearly made the biggest mistake of my writing career; when MI5 started late in 2002 looking for a historian to do their history

\footnotetext{
${ }^{17}$ See, https://www.chu.cam.ac.uk/archives/collections/papers-vasiliy-mitrokhin-1922-2004/.
} 
I originally was not going to apply because I hadn’t finished Mitrokhin II, which didn’t come out until 2005, although that had partly to do with some sensitive issues involving one or more foreign countries which were overcome, but there was the view that we should wait until after the following election to do that. So that again, in the year 2000, the idea that two years later I would be appointed official historian of MI5 with, until 2010, an office in Thames House, no, that didn’t occur to me.

\section{MP: I notice that the biographical note that accompanies the $1^{\text {st }}$ edition of The Mitrokhin} Archive II mentions that your authorized history of MI5 will be published in 2009.

CA: Yes, there was a deadline for that - MI5's centenary in 2009. They did not want a volume for their hundred and first birthday! I was appointed, I didn't begin work until 2003 and then of course the volume had to be written in plenty of time. Project management with a really big project is absolutely essential and getting it right to begin with is also absolutely essential. For example, it may sound a trivial thing, but the most important original decision I made was that I would start writing at 1945 and come up to more or less the present. My thinking then was that the later chapters would take some time to clear; what I hadn't realised is that the most difficult clearance issues would be not with the intelligence agencies but with other bits of Whitehall. I left the period 1909 to 1945 as the last thing to write because I assumed, as it turned out more or less correctly, that there would be very little contentious stuff in that. Then, I was very fortunate with the research team, all of whom like me were part-time. I suppose it would have been a half time job for me, although you yourself will have experience of doing three half time jobs - the arithmetic does not wholly work out. So, part-time I had three people within the office, one who had been effectively Head of Registry, a very nice woman with a wonderful memory who when I would say 'Is there a file on so-and-so?' would say, 'Oh yes, that's PF12345'! And then two others who had been what might be called operations officers, one of whom had been involved in the hunt for Bettaney ${ }^{18}$ for example, and then there were a couple of colleagues, one at the beginning of his career at Cambridge, the other at the end, who were half time or minus half time.

\footnotetext{
${ }^{18}$ Michael Bettaney, a former Security Service officer who passed information to Soviet officials in London and offered to work for the KGB. In 1984 he was sentenced to twenty-three years' imprisonment. See Christopher Andrew, The Defence of the Realm: The Authorized History of MI5 (London: Allen Lane, 2009), pp.714-24.
} 
The other thing that was agreed at the beginning and was absolutely essential is that there needs to be an overall plan. Now, as you know from your own experience, writing anything historical you have to reinvent the wheel every time because the problem is that time keeps moving forward. On the other hand, you never understand what's moving forward unless you stop from time to time and say, 'Well, the British economy looked roughly like this...' So, usually I think the best compromise is periodisation and then within the periodisation you can have some thematic chapters, so that is what I did and began each section with one chapter essentially on the personnel and recruitment. Somewhat to my surprise, because I imagined more flexibility would be required than was necessary, that plan remained pretty much intact until there were attempts by one or more parts of Whitehall to suggest that the book should be drastically shortened towards the end. After all, the SIS book, not through the will of its author, had to end in 1949. ${ }^{19}$ There was an attempt made by another department, after I had written most of the later stuff, that it should end in 1971. I'm delighted to say that the leadership stood firm and nobody afterwards complained that damage had been done.

\section{MP: You encountered some forms of resistance or second thoughts towards the end then?}

CA: The problems were not in MI5 or other intelligence agencies. The working agreement from the beginning was essentially that it was not up to me, and neither should it have been up to me, to decide what could be published and what couldn't. I was really struck by the degree to which some current agents are influenced by the degree to which the identities of their predecessors have been kept secret. That really does have an impact on the present. Now I've seen it in action I do understand it, but beforehand I was rather more sceptical. Let me give you one example; the Double Cross system begins, not on a huge scale but on a significant scale, in World War One and the best double agents are Americans. Why? Because until the Spring of 1917 they can travel freely in Germany. Of the best two double agents, one's name will probably never be revealed. His wishes at the time, not subsequently overridden by relatives, were that his identity should remain secret. So he's still known only by his codename COMO. The other leading American double agent was rather proud of what he'd achieved, and didn't mind his name coming out. British intelligence has actually been better at preserving the identities of its agents, far better than the Russians or Americans, for example. Precisely why

\footnotetext{
${ }^{19}$ Keith Jeffery, MI6: The History of the Secret Intelligence Service 1909-1949 (London: Bloomsbury, 2010).
} 
that is the case is a more difficult question. Obviously, I couldn't publish everything, and I really did not want to see anyway, and therefore did not ask to see, files on living agents. I didn't want to have to remember that I shouldn't remember that. Some of the technicalities of surveillance, well I probably wouldn’t understand it anyway. All I needed to know was what could be done and what in that period could not be done rather than the science of how it was done, if it was done. But I did make the point, which was instantly accepted, that in order to be certain about judgements I arrived at on the basis of material that I could publish, I needed to be sure that it wasn't contradicted by material that I couldn't publish. So there was a real relevance in looking at still withheld material.

\section{MP: The actual writing process would have taken around four years?}

CA: Well, no. I actually began quite quickly. I am a great believer in the Lego method of assembling history books, which is one that I recommend to all students. Once you have got an overview of what you want to do, and you have got the material on this bit and you know it is going to go in, well why not write up the bit that you have done? And you have got a general plan, which you may or may not change later, so I assembled an enormous amount of bits of Lego. The overall structure may evolve, but even in 2003 it was clear where it was going to end. It was going to end with how successful or otherwise counterterrorism was in the early twenty-first century, so I knew the ending.

I had an encrypted computer on which I did not keep classified material but did have drafts. All the classified material remained firmly in Whitehall. I had no operational responsibility at all. I didn't even have to become a member of MI5 and the late, great Keith Jeffery remained a so-called ‘contractor' for SIS. Actually, rather oddly, he wasn't an official historian but wrote an official history, I was an official historian but wrote an authorized history, which is the right way because nobody is committed to my interpretation other than me. The point that somebody made to me is that with any organisation, and this would be true of Leicester University and MI5, people speak to you more frankly if you are a member of the organisation than if someone comes poking about and says 'what did you do that for?' One of the days I will never forget was being there on 7/7 and seeing how people reacted to this terrible terrorist attack. I was very impressed by the fact that people were not saying, 'Oh well, we've done the best that we can, we couldn't have prevented this'. They were really asking themselves if there was anything more they could have done. 


\section{MP: Having produced histories of British, US and Soviet intelligence in the $20^{\text {th }}$ century,} how would you characterise the key differences between Western and Soviet approaches to intelligence?

CA: I think that with all the weaknesses, a global view might be that with their resources the British do it as well as anybody, but they have this enormous asset which derives from the Second World War of having a very close link with the state that spends more money on it and has more high technology than anybody else. It's the combination of those two, but I was acutely conscious of the importance of the culture and, even though it doesn't work with all ministers - how could it possibly? - the ability to connect with Whitehall, and that is something that counterterrorism has made far easier. You may or you may not be interested in British intelligence assessments of Iran or whatever, but you are certainly interested in intelligence assessments of the threat posed to the lives amongst other things of the Thatcher and Major governments. I was interested for example in Michael Herman's attempt to work out which was the number one intelligence priority, and the Soviet Union and the IRA turned out to be equal first. ${ }^{20}$ I thought that was really important and interesting.

MP: What are the key themes for you that emerge from your history of MI5? For example, I read it as primarily an account of the professionalization and institutionalisation of intelligence - from the era of the gifted amateur on the fringes of government to an established profession very much central to it.

CA: I wouldn't disagree with that except to say that it is a professionalization in some ways that is kept in bounds. There were periods when it wasn't professional enough, but from the moment that everything is reduced to performance indicators and box-ticking you are missing something really rather important. So the way that I would put it is the secret of success in any area of administration, ranging from intelligence services to universities, is the combination of tradition and innovation. There is a foolish but very prevalent view that any respect for tradition is just retrograde. But in Cambridge, for example, you have the combination of a largely traditional college structure plus the biggest science park in the country and each feeds off the other. They are not two separate compartments. So I think that in many ways it is something that is easier to grasp within a British context than it is in the context of most other countries,

\footnotetext{
${ }^{20}$ Mark Phythian, 'Profiles in Intelligence: An Interview with Michael Herman', Intelligence and National Security, Vol.32 No.1 2017, pp.1-8, at p.4.
} 
and also something of which quite a large percentage of people are aware. So a professional culture which also has good human relations. Intelligence can be over-bureaucratised, I think that is the important thing. Amateurism has had too bad a press, in other words.

Experience is as important as new technology, but not enough is done to learn from it. It would be worth spending more time looking back at horizon scans of ten, twenty, more years before, and asking the following questions: What did we get right? Why did we get it right? What did we get wrong? Why did we get them wrong? These questions sometimes yield surprising answers. Just one example. The biggest lack in Western intelligence a generation ago, and one can certainly take it back as far as the late 1970s, was a lack of theologians. Now, you would never arrive through any modern business practice at an awareness that you needed theologians. So what happens? It means that at the end of the twentieth century we understand the opposition, Islamic extremists, less well than we had understood the opposition in World War Two. No government department which had to deal with Nazi Germany would have even thought of omitting people who were expert in, amongst other things, Nazi ideology. And again during the Cold War, the idea that you pay no attention to the ideology. But there was a difficulty in the secularised late twentieth century of taking the ideology of Islamist extremists seriously, that it is point. If one takes a long view of terrorism then you arrive at the notion, which is not mine of course, that the dominant form of terror until the French Revolution was holy terror. Even though he may have meant it in a slightly different context, that terrible Alastair Campbell phrase, 'We don't do God' - actually British intelligence, Western intelligence generally, didn’t ‘do God’ in 1979, which is why they couldn’t grasp how a young, idealistic, highly-radicalised people wanted a geriatric theologian to be their political and spiritual leader. Those difficulties essentially continued until 9/11.

It is those kinds of consideration which led me to try to take a really long view. My next book begins with the following sentence; 'The first person of any significance in world history to emphasise the need for good intelligence was God.' And I then report his dialogue with an uncomprehending Moses who messes it all up, so it's 40 years in the wilderness. Not many intelligence failures lead to punishment quite that dire! Well, fast-forward to the beginning of the New Testament, Matthew's Gospel, which gives Jesus’ genealogy; straightforwardly miraculous on his father's side, more complex on the female side where he's descended from a series of remarkable women, the first of whom is also the first really celebrated female spy in world history, Rahab the harlot, the woman who helped Joshua and his men enter Jericho. 
MP: Across all of these projects is there any one that has given you greater satisfaction or that you regard as your greatest achievement as a historian?

CA: Probably not, but the reason is simply that I'm always thinking of the next book by the time the last one comes out. The one that gives me the greatest satisfaction, I think, is the one that I am doing at the moment, Secret World: The Making of Modern Intelligence from Moses to the Twenty-First Century (to be published by Penguin in 2018). Much of what I've done before, for logistical reasons, was largely but not wholly within geographical boundaries. If you've got the files of the KGB in front of you, that's what you write about. If you've got the files of MI5 in front of you, ditto, and American intelligence agencies as well. So, this book gives me the possibility of pulling all that together and putting it in a much longer-term perspective which I seek to show is relevant to the present.

\section{MP: In working on Secret World what has struck you most, the transformations in intelligence practice or the continuities?}

CA: I think fundamentally the continuities. I wouldn’t myself draw a conceptual distinction between intercepting a message on parchment and intercepting a message in the ether. Though the methodology has to be seriously different, it is essentially the same operation. The continuities in intelligence assessments and passing these assessments to policymakers are also more striking than the differences. The problems of 'telling truth to power' also haven't changed fundamentally over the last few thousand years. Because of the pressure to tell authoritarian regimes only what they wish to hear, they always have been and always will be second-rate when it comes to the understanding of intelligence.

Authoritarian regimes and their intelligence agencies are also more susceptible to conspiracy theories about their opponents at home and abroad. In the summer of 1960, for example, Shelepin ${ }^{21}$ hand-delivers to Khrushchev a document saying the KGB have discovered that the Pentagon is preparing a first-strike against the Soviet Union (which of course it wasn’t), and less than a fortnight later Khrushchev gives that famous speech saying in effect: 'Don't even think about it, we can hit targets to within a few metres.' Then in the Spring of 1962 the GRU tells Khrushchev that actually there had been an American intention to launch a first-strike in

\footnotetext{
${ }^{21}$ Alexander Shelepin, head of the KGB from late 1958 to late 1961.
} 
the previous September, 1961, but they hadn't done it because they had concluded from Soviet nuclear tests that even after such an attack the Soviet Union would retain a second-strike capacity. It is in the weeks after that that Khrushchev decides to put missiles in Cuba.

Compare and contrast that with what is going on in Excomm in Washington during the Cuban missile crisis. One of the books I will never write, but someone should write, is a history of committees. We are all on committees. The first thing we notice about them is they are often boring. The thing that we fail to notice about them is that they are one of the greatest achievements of the human spirit. Everyone on Excomm is qualified to discuss these issues, they get the latest intelligence every day, sometimes more than once a day, everybody is free to give their own interpretation. Impossible in Moscow. The understanding of how authoritarian regimes behave and use intelligence cannot possibly be obtained from a study of the twentieth century alone.

\section{MP: What do you think are the outstanding challenges for the current and next generations of intelligence historians?}

CA: Michael Herman is quite right to say that there needs to be a global view. ${ }^{22}$ But I think we can already deduce something of considerable importance. The West was never in the lead so far as intelligence is concerned until the Renaissance. Sun Tzu and arguably the Arthashastra out-performed anything available in the West, and there is no doubt at all that a thousand plus years ago the main centre of scientific research in the world, which was the House of Wisdom in Baghdad, was also the world's leader in codebreaking. It was the House of Wisdom which for the first time solved Caesar's cipher, for example. And then the Ottomans refuse to allow printing, so from the moment that you get the banning of printing in Turkey when it takes off in the West, then the West out-classes the rest of the world in all kinds of ways. From the point of view of intelligence there is absolutely no doubt in my mind that just as the House of Wisdom had been in a different class from Western competition five hundred years earlier, by the Renaissance the Ottomans can no longer break codes. They have actually lost the great work on how to do it, which turns up now 15 years ago, believe it or not, in a library in Istanbul.

The West rediscovered Sun Tzu's The Art of War ahead of China. Probably the first person in Britain, apart from somebody in the British Museum, to read it was Sir Vernon Kell, who was

\footnotetext{
${ }^{22}$ Phythian, 'Profiles in Intelligence: An Interview with Michael Herman', p.6.
} 
an extraordinary linguist, the only head of a British intelligence agency to my knowledge who had translator's qualifications in Chinese - he had been in China during the Boxer Rebellion. Kell also had a translator's qualification in Russian and could translate other Western European languages as well. Only later do Mao and others in twentieth-century China grasp the importance of The Art of War and what it says about intelligence.

\section{MP: You used the term 'the missing dimension' to characterise the state of historical research into intelligence in the mid-1980s. How far have we gone beyond 'the missing dimension'? How far has this been rectified now?}

CA: There are still a lot of areas of even British history in which the historiography has got so cramped between traditional boundaries that it can't cope with it. For example, with regard to the Labour Party, the British Prime Minister who at his own request saw the Director General of MI5 one-on-one far more frequently than any other Prime Minister of the twentieth century was Clement Attlee. Now, what was he on about? Well, if you were a communist and wished to be elected to the French parliament (ditto the Italian parliament), no particular problem. Their communist parties were extremely popular. By contrast, if you were member of the unpopular British communist party and wished to be elected, by far your best chance was to pose as Labour, and that is why Attlee wanted to speak to the DG as often as he did. As late as 1961 Hugh Gaitskell sends George Brown and others along to deliver to MI5 a list of sixteen Labour MPs that they wish to be investigated because they believe they are actually communists. Number one on the list being Will Owen, MP for Morpeth, whose file in the StB, the Czechoslovak intelligence service, identifies him as fully paid-up. MI5 thought by now that the leadership of the Labour Party was a bit over-excitable on this and so didn't in fact investigate.

The difficulty of giving due importance to the missing dimension is not encountered so much in relatively new areas of research but in fields where there is already a solidly established body of estimable literature, as for example on the history of the Attlee government. Breaking into that and saying: 'Here is something really important that you have not considered and don't at the present time look even inclined to consider', that's arguably the biggest challenge.

The final thing that I would say is that Russian intelligence is not good at analysing its strengths and weaknesses in the twentieth century. Paradoxically, it's rather better for the sixteenth, seventeenth, eighteenth and nineteenth centuries because, and this might fit your point about 
ideology, there's not an ideological problem there. One of the things that struck me when I went to Archangel recently, there is a little monument to a Richard Chancellor who was seriously off-course but nonetheless landed there and began trading relations, having been taken up by Ivan the Terrible. ${ }^{23}$ But the SVR official history, which goes back to the sixteenth century, unlike mine, which only manages to get back to Victorian times, says how impressive it is that you could have this English boat arrive at one of the furthest extremes of Russia and that news of the arrival of an intruder should be brought straight to the authorities who then sent it to Ivan the Terrible. A really interesting insight, it seems to me - the idea that the SVR understands Ivan the Terrible better than it understands Stalin, I find quite intriguing.

MP: A very interesting story to finish with. Thank you very much for your time.

\section{Christopher Andrew: A select bibliography}

Théophile Delcassé and the Making of the Entente Cordiale: A Reappraisal of French Foreign Policy 1898-1905 (London: Macmillan, 1968)

'The French 'Colonial Party’: Its Composition, Aims and Influence, 1885-1914', with A. S. Kanya-Forstner, Historical Journal Vol. XIV No.1 1971, pp.99-128.

'Déchiffrement et diplomatie: Le cabinet noir du Quai d’Orsay sous la Troisième République', [Decipherment and Diplomacy: The Black Chamber in the Third Republic] Relations Internationales Vol.III No.5, 1976, pp.37-64.

'Whitehall, Washington and the Intelligence Services', International Affairs Vol.53 No.3 1977, pp.390-404.

\footnotetext{
${ }^{23}$ Richard Chancellor landed at Archangel in 1553. On Chancellor, see James McDermott, 'Chancellor, Richard (d. 1556)', Oxford Dictionary of National Biography, Oxford University Press, 2004 [http://www.oxforddnb.com/view/article/5099, accessed ‘6 Feb 2017].
} 
'The British Secret Service and Anglo-Soviet Relations in the 1920s Part I: From the Trade Negotiations to the Zinoviev Letter', The Historical Journal Vol.20 No.3 1977, pp.673-706.

'Governments and Secret Services: A Historical Perspective’, International Journal Vol.34 No.2 1979, pp.167-86.

France Overseas: The Great War and the Climax of French Imperial Expansion, with A.S. Kanya-Forstner (London: Thames and Hudson, 1981).

'British Intelligence and the Breach with Russia in 1927', The Historical Journal Vol.25 No.4 1982, pp.957-64.

The Missing Dimension: Governments and Intelligence Communities in the Twentieth Century, edited with David Dilks (London: Macmillan, 1984).

'France and the German Menace', in Ernest R. May (ed.), Knowing One’s Enemies (Princeton, NJ: Princeton University Press, 1985), pp.127-49.

Secret Service: The Making of the British Intelligence Community (London: William Heinemann, 1985).

'F. H. Hinsley and the Cambridge Moles: Two Patterns of Intelligence Recruitment', in Richard Langhorne (ed.), Diplomacy and Intelligence During the Second World War: Essays in Honour of F. H. Hinsley (Cambridge: Cambridge University Press, 1985), pp.22-40.

‘Codebreaking and Signals Intelligence', Intelligence and National Security Vol.1 No.1 1986, pp.1-5.

'Tsarist Codebreakers and British Codes', with Keith Neilson, Intelligence and National Security Vol.1 No.1 1986, pp.6-12.

Intelligence and International Relations 1900-1945, edited with Jeremy Noakes (Exeter: University of Exeter Press, 1987).

The Growth of Intelligence Collaboration in the English-Speaking World (Washington, DC: Wilson Center, 1987). 
'Historical Research on the British Intelligence Community', in Roy Godson (ed.), Comparing Foreign Intelligence: The US, the USSR, the UK and the Third World (Washington, DC: Pergamon-Brassey’s, 1988), pp.43-64.

‘Churchill and Intelligence’, Intelligence and National Security, Vol.3 No.3 1988, pp.181-93.

'The Growth of the Australian Intelligence Community and the Anglo-American Connection', Intelligence and National Security Vol.4 No.2 1989, pp.213-56.

KGB: The Inside Story, with Oleg Gordievsky (London: Hodder \& Stoughton, 1990).

Instructions from The Centre: Top Secret Files on KGB Foreign Operations 1975-1985, with Oleg Gordievsky (London: Hodder \& Stoughton, 1991).

'The British View of Security and Intelligence', in Stuart Farson, David Stafford and Wesley K. Wark (eds.), Security and Intelligence in a Changing World: New Perspectives for the 1990s (London: Frank Cass, 1991), pp.10-24.

'The Nature of Military Intelligence', in Keith Neilson and B. J. C. McKercher (eds.), Go Spy the Land: Military Intelligence in History (Westport, CT: Praeger, 1992).

More Instructions from The Centre: Top Secret Files on KGB Global Operations 1975-1985, with Oleg Gordievsky (London: Frank Cass, 1992).

'KGB Foreign Intelligence from Brezhnev to the Coup', Intelligence and National Security Vol.8 No.3 1993, pp.52-67.

'The Making of the Anglo-American Sigint Alliance', in Hayden Peake and Samuel Halperin (eds.), In the Name of Intelligence: Essays in Honor of Walter Pforzheimer (Washington, DC: NIBC Press, 1994), pp.95-109.

For the President's Eyes Only: Secret Intelligence and the American Presidency from Washington to Bush (London: HarperCollins, 1995).

'Anglo-American-Soviet Intelligence Relations', in Ann Lane and Howard Temperley (eds.), The Rise and Fall of the Grand Alliance, 1941-45 (London; Palgrave Macmillan, 1995), pp.108-35. 
'American Presidents and Their Intelligence Communities, Intelligence and National Security Vol.10 No.4 1995, pp.95-112.

'Introduction to 'The ISOS Years: Madrid 1941-3”, Journal of Contemporary History Vol.30 No.3 1995, pp.355-8.

Eternal Vigilance? Fifty Years of the CIA, edited with Rhodri Jeffreys-Jones (London: Frank Cass, 1997).

'Intelligence and International Relations in the Early Cold War', Review of International Studies Vol.24 No.3 1998, pp.321-30.

The Mitrokhin Archive: The KGB in Europe and the West, with Vasili Mitrokhin (London: Allen Lane, 1999).

'Witness Seminar: The Intelligence Services in the Second World War', edited with Richard J. Aldrich, Contemporary British History Vol.13 No.4 1999, pp.130-69.

'Stalin and Foreign Intelligence', with Julie Elkner, Totalitarian Movements and Political Religions Vol.4 No.1 2003, pp.69-94.

'Intelligence, International Relations and 'Under-Theorisation”, Intelligence and National Security Vol,19 No.2 2004, pp.170-84.

'Intelligence Analysis Needs to Look Backwards Before It Can Look Forward', Policy Paper, History and Policy, June 2004, available at: http://www.historyandpolicy.org/policypapers/papers/intelligence-analysis-needs-to-look-backwards-before-looking-forward.

The Mitrokhin Archive II: The KGB and the World, with Vasili Mitrokhin (London: Allen Lane, 2005).

Secret Intelligence: A Reader, edited with Richard J. Aldrich and Wesley K. Wark (Abingdon, Routledge, 2008).

The Defence of the Realm: The Authorized History of MI5 (London: Allen Lane, 2009). 
'Still the ‘Missing Dimension’: British Intelligence and the Historiography of British Decolonisation', with Calder Walton, in Patrick Major and Christopher R. Moran (eds.), Spooked: Britain, Empire and Intelligence since 1945 (Newcastle; Cambridge Scholars Publishing, 2009), pp.73-96.

An International History of the Cuban Missile Crisis: A 50-Year Retrospective, edited with David Gioe and Len Scott (Abingdon: Routledge, 2014).

Interrogation in War and Conflict: A Comparative and Interdisciplinary Analysis, edited with Simona Tobia (Abingdon: Routledge, 2014). 